\title{
Narratives of Truth: An Exploration of Narrative Theory as a Tool in Decolonising Research
}

\author{
Markus Nyström
}

\section{Introduction}

This anthology is about cultural and linguistic revitalisation. Narratives, or stories, are, I believe, the perfect middle ground between these two concepts, between culture and language. It is difficult to imagine a culture without shared language and stories, and it is probably inaccurate to call the existence of shared language and stories anything other than a culture. As part of the Sami revitalisation of culture and language, I believe stories are central. But as a white, Swedish man brought up in the south of the country, I firmly believe it is not my role to tell or analyse Sami narratives. My role, instead, has to be to turn my critical eye towards those in power, towards my own culture-towards myself. I was raised in a country whose colonial past (and present) is most often absent in the narratives told about the country, and first came into contact with this history as an adult and never in school. This chapter is as much about me as it is about the political discourse in which I exist. This chapter is therefore an attemptto some degree- to 'unsettle the settler within' (Regan 2010: 11) by trying to expose colonial mindsets towards Sami and Sapmi in Swedish political discourse, the discourse I was brought up in. 
I believe that for Sami, especially young Sami, creating new and holding on to old narratives and understandings might be crucial in the revitalisation process. But, in that process it is also important to have tools to see through and criticise the dominant narratives, as well as form counter narratives. My hope is that this chapter will make available one such tool by showing how concepts from narrative theory can be used to analyse political discourse. ${ }^{1}$ My claim, or hope, is that narrative theory, and especially the concept of a masterplot, can function as a means to expose that which may not be explicit, but assumed, in a discourse. As a master's student in Environmental History, at the time of writing, researching the Swedish discourse on mining in Sapmi, it became, and still is, quite clear to me that there are dispositions, attitudes and knowledge formations in the political discourse which stem from colonial relations, but which are difficult, or even impossible, to positively pinpoint when analysing the discourse. The concept of a masterplot may be, in some cases, a way of doing just that - a way of pinpointing where and how a covert colonial 'mindset' is present in a discourse. By exposing how colonial mindsets are infused in a discourse, it is my hope that it will be easier to oppose and resist them, and thereby support a revitalisation or decolonising process.

I will attempt to explain my method in detail and then apply it to a selection of debates in the Swedish parliament relevant to Sami affairs. Before getting into the method, and before beginning the analysis, I need first to establish what I regard as colonialism and what, in this article, I call colonial mindsets.

1 In this chapter, 'political discourse' refers to mainstream political discourse, the political hegemonic discourse. More specifically, the way people in political power, in the parliament and government, speak and construct their world view. 


\section{Colonialism and colonial mindsets}

Colonialism can be a rather imprecise concept, spanning various phenomena and methods of domination, and definitions available through dictionaries are often vague or even misleading. ${ }^{2}$ The problem with a succinct definition is that it easily becomes either too narrow or too vague to be of much analytical use. A well-functioning analytical definition must be rather elaborate and sensitive to variations in colonial methods. There is simply not enough space to create such an elaborate definition here, but my work so far has resulted in an understanding of colonialism as functioning in two main categories: the ordering of physical/political reality on the one hand, and the ordering of ideological/ontological reality on the other.

The ordering of physical/political reality includes domination of a territory and/or a people by an external power (a nation state, empire, corporation). Military force or police violence is often present, or at least the threat thereof. Domination is a key concept because it denotes the inequality of power and control between the colonisers and the colonised. Colonialism includes the permanent settlement of significant numbers of colonists, or the establishment of strong enough institutions, or large enough industries, on the colonised land against the will and/or interests of the colonised people. Imperialism-a closely related concept-refers mainly to domination without significant numbers of permanent settlers, and refers to a larger degree to the ideological backdrop of colonialism. Imperialism can be seen as the idea that a country/polity/corporation has the right to expand at the expense of others; colonialism is that idea's most spectacular expression (Smith 1999; McLeod 2000). It is also important to note that the driver of colonialism (and imperialism) is the economyaccess to resources, expansion of markets, cheap labour. Even though other

2 The Oxford online dictionary, for instance, defines colonialism thus: 'The policy or practice of acquiring full or partial political control over another country, occupying it with settlers, exploiting it economically'. Note that there is no subject doing the colonising, but it can be read implicitly (since it is 'another country' being colonised) that colonialism is something countries do, not corporations, federations, or other units of power. Furthermore, it says nothing of the 'colonisation of the mind', of colonial discourses, or ruptured identities. Many former colonies were not technically countries at all at the time of colonisation, but were constructed as countries by the colonisers. With this definition, colonialism cannot occur within the borders of one country, as in Sweden. Sapmi has thus not been colonised for two reasons: it was not 'another country' and it was (and is) technically within the borders of Sweden. 
'well-meaning' reasons for the expansion of empires has been proposed'the white man's burden', or saving the souls of not yet baptised heathens, for instance-the main driver remains economic gain.

The second category, the ordering of ideological/ontological reality, refers to the psychological violence which shatters identities and creates new ones. This has aptly been called the 'colonization of the mind' (Thiong'o 1986). Colonial discourses are naturalised that posit the colonisers as righteously dominant, and through religious, educational, scientific, moral, legal and bureaucratic institutions, colonial discourses are maintained and internalised by the colonised people themselves. This internalisation is central because colonialism does not work merely by a colonising power imposing itself on a society which actively resists it. Instead, colonialism functions by the colonised people internalising the narratives of the colonisers - in a word, the colonised are forced, through various means, to see the world and themselves in the same way as the colonisers do. The internalisation of colonial discourses is a key instrument of power. This is why narratives are so central in a revitalisation or decolonisation process, because they can entail rejecting the internalised colonial discourses and regaining narratives, identities and pride that were lost.

A definition focused only on the ordering of physical/political reality must necessarily regard colonialism as past and over the day the native flag is raised instead of the flag of the colonial power. But this is not how colonialism works. Colonialism lingers in the minds of people; it is passed down through generations, by means of the psychological violence of the colonisation of the mind. Just because the wording in political discourse or some nationalistic formalities change does not mean that the (former) colonising power regard the (former) colony differently, or that the (former) colonised people regard themselves or the (former) colonisers very differently either. It is easier to change a flag than the world views, narratives and identities of people who have suffered for centuries under the yoke of colonialism. Colonialism cannot be regarded as an on/offpractice. Despite formal decolonisation, colonial practices can still be in place. This is often referred to as neo-colonialism.

And this leads to the subject of this article, because not since the beginning of the twentieth century has the political discourse in Sweden included an explicitly colonial perspective on the north. The debate around the turn of the twentieth century concerned whether this colony of Sweden ought to be an agricultural or industrial economy (Sörlin 1988). For roughly 
a hundred years, therefore, Sweden has officially or explicitly not colonised Sapmi. Yet, during this same period, enormous increases in industry in Sapmi have occurred, a number of divisive and ill-advised laws have been passed with relevance to Sami livelihoods, reindeer herders have been displaced, racism toward Sami has been and is still widespread, and large numbers of Swedish settlers have migrated to Sapmi, to give just a few examples. In many ways, the colonial efforts of the Swedish state have increased simultaneously as the word colonialism has all but disappeared from the political discourse and agenda (Lundmark 2008). So, in short, during the same time as the physical/political reality has been ordered to exploit Sapmi to an ever higher degree (physical/political reality), and during the same time as Sami livelihoods, identities and languages have been systematically degraded through state actions (ideological/ontological reality), the narratives describing the relationship between Sapmi and Sweden have been transformed to virtually give the opposite view.

This lack of explicitness in the Swedish political discourse concerning the relationship between the state and Sapmi brings two distinct problems. The first is that it is difficult for a researcher (or anyone) to find actual and explicit colonial statements in current political discourse. In a positive research tradition, where one analyses what is actually said — not what is not said — this makes for a difficult methodological problem. Finding ways to circumnavigate this problem is important since silencing and rendering invisible are highly effective instruments of power, common in colonial relations - and analysing power structures ought to be an important goal for academic work. At the same time, there is a methodological problem with leaving it entirely up to the individual researcher to 'speculate' as to what is not said, to 'read between the lines'. Investigating the invisible and untold, or rather the implicit and assumed, therefore, needs stringent methods and theory in order to work well.

The second problem that arises from this lack of explicitness is that even the proponents of further exploitation of Sapmi and further delimiting of Sami rights (for instance, Sweden's former minister of commerce, Annie Lööf) do not regard themselves as proponents of colonialism. Instead, they may regard themselves as proponents of, for instance, economic growth and equality. In other words, without access to the explicit terminology of colonialism in the political discourse, colonial actions are cloaked not only from researchers but also from the colonialists themselves. In effect, they cannot be colonialists because colonialism does not exist in their discourse. This is where I choose to introduce the concept of colonial 
mindset. Simplified, one has a colonial mindset if one's actions and rhetoric (or narratives) have colonial outcomes and/or origins without explicitly using a colonial vocabulary. A politician, for instance, reveals a colonial mindset when arguing for a continuation or increase of colonial policies and practices, or subscribes to and uses colonial narratives and masterplots to describe reality at the same time as his/her rhetoric hides colonial aspirations. The term colonial mindset is thus closely tied to neo-colonialism. I choose this term because it is my understanding that politicians who actually promote colonialism, but call it something else, sincerely believe themselves not to be promoting colonialism.

\section{Narrative theory}

The word narrative is often used synonymously with story. We like to think of narratives as art, however modest, and we think of writers, filmmakers and playwrights as good storytellers. They are people who master the art of narrative. But narrative is a larger concept than story. Narrative is something we all engage in all the time: it is our species' 'principal way' of organising our understanding of time (Abbott 2008: 3). Paul Ricœur wrote his three-volume opus titled Time and Narrative, where

one presupposition commands all the others, namely, that what is ultimately at stake in the case of the structural identity of the narrative function as well as in that of the truth claim of every narrative work, is the temporal character of human existence (1983: 3).

But what does it mean to organise the 'temporal character of human existence'? A quick answer could run something like this: when we tell of something-let's say, how our day at work was-we do not tell of everything that happened during the day. We choose to convey certain events that make the listener understand our day; events that exemplify and explain, in other words, create meaning. Compare this kind of narrative to a story dictated by clock-time, a so-called 'pure chronicle' (Cronon 1992: 1351), an objective story, as it were, where no interpretation of meaning is made. This would be a story in which clock-time-not meaning or importance-would dictate our telling of our day. Every event that occurred during the day would receive the same amount of attention, given that it took the same amount of clock-time. 
This is why Ricœur says that narrative is the method we humans use to create an understanding of 'human time'. By narrative, we make our telling of our work day 'human'. Narrative is the way for us to make sense of things. A pure chronicle does not make sense to us, no matter how 'objective' it might be. That it does not explain things sufficiently is, at a first glance, rather ironic since it seems to offer an unbiased representation, which ought to be attractive to the rational mind. But this sense of irony probably comes from the idea (or ideal) that humans are primarily rational beings, while we in fact are at least as much, if not more, narrative beings. In this perspective, narrative is a central human trait. Indeed, it has been argued that the propensity for narrative is what distinguishes humans from other animals; that narrative is 'the central function or instance of the human mind' (Jameson 1981: xiii). We cannot avoid engaging in narrative activity.

There are four more concepts that need further examination in this article. They are plot, masterplot, type and plotline. These concepts have more to do with what are usually referred to as 'stories' than the more instinctual or reflexive narrative thinking described above.

A plot is, according to Ricour and his reading of Aristotle, an operation, not a static structure, which creates a 'synthesis between heterogeneous elements'; a plot 'serves to make one story out of ... multiple incidents' (Ricœur in Wood 1991: 21). A plot has a wholeness to it, a beginning, a progression and an end, and events are more than just occurrencesevents are what contribute to the progression, beginning and end of the plot. This has some interesting repercussions, namely that events are to some degree chosen to belong to a narrative insofar as they contribute to the (preconceived) plot. In other words, a plot is never neutral but constructed with particular goals in mind-whether the narrator is conscious or not that he/she is doing so.

This brings us to the idea of masterplot and type. A masterplot is a plot that is easily recognised by members of a culture and oft-repeated in various forms. Sometimes referred to as master narratives or story skeletons, masterplots are plots that we hear and see over and over again within a specific culture's narrative tradition (Abbott 2008). When we start watching a movie and have a pretty good idea after three minutes how the story will progress and end, there is a good chance we are dealing with a masterplot. Classic masterplots for western culture are for instance the Quest (Exodus, Lord of the Rings), the Escape (The Count of Monte Cristo, 
Midnight Express), the Sacrifice (Jesus Christ, Saving Private Ryan), the Forbidden Love (Romeo and Juliet, Titanic). See, for instance, Ronald B. Tobias's list of masterplots, 20 Master Plots and How to Build Them.

Masterplots are more than just stories we know. This is important. They are operations by which we interpret reality; they are 'mental maps' onto which we try to fit the reality we see outside ourselves even if it does not fit very well (Abbott 2008: 46). Masterplots are, as it were, culturally sanctioned templates for interpreting reality around us.

What constitutes a masterplot exactly is hard to say. But they often, if not always, come with specific types. A type is a recurring kind of character (Abbott 2008: 49). The troubled but daring seeker of the Quest masterplot and the tormented and wise martyr from the Sacrifice masterplot are examples. When a type is too shallowly described, and appears too predictable, we often call the character a stereotype. Masterplots can also be rendered stereotypically, in which case the narrative appears as too simple, shallow and clichéd.

A plotline, finally, denotes the development within a plot, whether it ends better or worse than it starts. It's a rather vague concept academically perhaps, but a concept nonetheless that I find quite intuitive. Are things better in the end of a plot than in the beginning? Are the characters (the types) wiser, richer, more mature-or the opposite? The characters in a Quest masterplot are often wiser and richer in the end than in the beginning, even if the quest has its toll, while one or both of the lovers are dead in the Forbidden Love masterplot.

So how can this framework, this terminology, be used in order to highlight colonial mindsets? How can it be used to investigate the invisible and untold, the implicit and assumed? By drawing two conclusions. First, we can assume that the history of colonialism and racism has generated a number of colonial masterplots, or masterplots with importance for colonial mindsets. I will try and list a few of these below that I believe I can identify. These colonial masterplots are 'mental maps' which people repeatedly put to use in order to interpret and describe the world around them.

Second, narrative activity is a central human trait; we reflexively organise our understanding in the form of narratives, and masterplots are almost instantly recognisable to us. This means that a speaker does not have to tell the entire masterplot narrative in order to activate the rhetorical leverage, 
the force, of that masterplot. A single phrase can turn the listener's mind in the direction of a familiar masterplot, encourage him/her to interpret the narrative in that light, and in turn also try to fit the characters of the narrative into the types of that masterplot. A proud 'I'm going on a mission' as one heads out to the supermarket comically draws on the Quest masterplot; a concerned 'She's your Juliet' from a friend can draw attention to the hopelessness of a relationship you are in by drawing on the Forbidden Love masterplot.

And conversely, and maybe more importantly, these masterplots, being part of our cultural metaphoric vocabulary as it were, can frequently be expressed unintentionally. Saying, for instance, that Norrland is 'wild' and 'desolate' are such standard expressions they usually pass us without much notice (even though what today is called Norrland has been populated since the last ice age (see Hagström Yamamoto 2010). These words, I would argue, are all expressions of a masterplot about Norrlandor possibly colonised lands in general-that render the Indigenous population invisible and portray the land as 'up for grabs'. ${ }^{3}$

Masterplots can sometimes even be woven into the discourse on a linguistic level, that is, into the words themselves. Above I wrote about 'Norrland', but I did so partly ironically. Norrland (literally, 'North Land') is what constitutes roughly half or more of Sweden's landmass, and it is obviously named so because the people who defined and named it were to the south if it. 'Norrland' is north of whatever and whoever is important enough to define the world. Within that word-Norrland-an entire masterplot could arguably be read.

\section{Colonial masterplots}

I try here to list a few colonial masterplots that I can identify. Masterplots are arbitrary in the sense that there is no formula to easily demarcate them. They often overlap (the Escape and the Quest masterplots described above could, for instance, be said to belong to an even larger masterplot going back to ideas of Purgatory). Someone else making a list like this would

3 An obvious example of this was when the CEO of Beowulf Mining, a company that is planning to start a mine in Gállok outside Jokkmokk, Sapmi, answered the question of what the local people would think of the mining project with a rhetorical question, 'What local people?' I call this masterplot the Terra Nullius masterplot (elaborated below) from the Roman expression for 'no man's land'-which goes to show how old this masterplot is in colonial relations. 
possibly end up with a different categorisation than I. I mainly make this list to exemplify to the reader what I mean by masterplots, since I believe this list makes the theoretical talk above more concrete. This list is not exhaustive.

\section{The Terra Nullius masterplot}

The land is empty, up for grabs, and the plotline suggests that the land not only can but deserves to be 'improved' (Cronon 1992: 1351). The land is of course not really empty at all but is generally perceived as such, as the original occupants are lacking the rights to the land for one reason or another (they are not organised into nation states, they are not Christians, they are not farmers). The land itself is an important type in this masterplot. The land is what is developed by a nation, an industry or a people, who make it-in their eyes-better. (Narratives: countless westerns, Star Trek, colonial historiographies, Columbus 'discovering' the 'new world'.)

\section{The Robinson Crusoe masterplot}

This shares a lot with the Terra Nullius masterplot but is more individualistic. A lone survivor, an adventurer, a settler or entrepreneur leads the way in this 'empty' land. The focus is on toil and hardships, (western) ingenuity to solve problems and discovery of 'strange lands'. The protagonist (most often a man) can get to know the Indigenous people, but if he does, it is the Indigenous who are changed most dramatically by the encounter. The focus is on character development of the protagonist who most often returns to civilisation or is saved. (Narratives: Robinson Crusoe, Amundsen and Scott's competition to reach the South Pole, Meriwether Lewis, Lars Monsen: Kanada på tvers (Lars Monsen: Across Canada)).

\section{The Lost Culture masterplot}

A romantic or nostalgic masterplot seems to pay homage to the nobility of lost (or about-to-be lost) cultures, neglecting that many of these cultures still exist but do not fit the romanticised ideal of Indigenous people. This masterplot brings relief to the colonialists because the progression of 'civilisation' is regarded as more or less unavoidable. With unavoidability comes freedom from responsibility. The masterplot can end in roughly 
two ways. It can end with 'civilisation' progressing (as in Dances with Wolves) or with the resistance to it being too strong (as in Avatar). The plotlines can therefore vary. Types include the 'Noble Savage', the 'evil colonialist', and a westerner who is changed, who 'goes over to the other side'. (Narratives: Pocahontas, The Last Samurai, Lawrence of Arabia.)

\section{The Noble Savage masterplot}

In this version, the Indigenous peoples are portrayed as part of nature rather than culture. Their nobility, their inherent ecological savvy, is peaceful, harmonious and infantile. The influence of western culture is seen as harmful and the fragile 'children of nature' need protecting. The Indigenous person is not someone who makes much noise, does not drive a snow mobile, have a cell phone, or live in the city. When civilisation comes around, the Noble Savage slowly shakes his/her head and shies away, opting for the peacefulness of nature instead. This is a masterplot where the Indigenous do not change much, do not want change, and where indigeneity is something more or less fixed. It is up to benevolent colonialists to 'protect' them. Ultimately, however, this protection is futile as the progression of 'civilisation' is unavoidable. (Narratives: The Mission, Jimmy Nelson's Before They Pass Away.)

\section{The Development/Industrial Production/White Man's Burden masterplot}

I lump these together because they have much in common, and they could be seen as representing more of a thought structure, a red thread, common in many masterplots rather than a single masterplot in itself. The idea where 'raw materials' are transformed into 'finished products' is the linear production apparatus of modern industrial production; it is the masterplot of industrialism, as it were. This is not necessarily colonial, but the structure recurs in colonial masterplots. For instance, in the Terra Nullius masterplot, the 'raw material' is developed by colonial forces into a better state, and into a finished product. Obviously, the word 'development' is central here, involving change supposedly inherently for the better. This development is good, something everyone ought to want, but it is also exclusively defined as westernisation. In this sense, this masterplot is closely related to the idea of the 'white man's burden', justifying colonialism as a noble cause. Compare the white man's 
burden idea to the idea of 'developing countries' being thankful for the introduction of western technology and their inclusion into western institutions and economic systems.

\section{The Nation State masterplot(s)/narratives}

A similar linear development can be found in narratives about nation states, born out of dim and/or cruel beginnings, as they are often pictured, developed over time into glorious, powerful and naturalised institutions. Narratives about nations can take a number of forms and plots-Rise/ Fall, David/Goliath, Good/Evil—but what makes nation state narratives important to bring up is that they work to unify, in some sense to make, a homogenous 'people', no matter what masterplot(s) the narratives employ. Not infrequently, this is done through the reminiscence and nostalgia over a more or less imagined lost past (Lahtinen 2012). A 'national history functions like a "story of the tribe", providing the people with a sense of shared origins, a common past and a collective identity in the present' (McLeod 2000: 70).

\section{Masterplots and narratives used in political debate}

Using masterplots, types (and stereotypes), and plotlines can be done in a number of ways for a number of purposes. Their use is rather flexible. They can be employed sarcastically, earnestly, sympatheticallyintentionally or not. Going through text-especially rule-bound, dry parliamentary debates, as I do below-in the hope of finding clear-cut and obvious uses of colonial masterplots can be difficult. In this dry genre, stories, as we usually think of them, are largely missing. Instead, 'statements of fact' (descriptions of how the world is or ought to be) dominate the genre. Of course, what is regarded as 'statements of fact' are political and ideological and the 'matter-of-factness' way of speaking is a rhetorical device aimed at making the speaker appear more convincing and thus making counter arguments more difficult. Very little hedging is done and expressions of feelings are rare in parliamentary debates. Quite a substantial amount of effort is spent by politicians bashing opposing parties, throwing numbers and statistics at each other, and other 
devices aimed at specific parties and alliance formations between parties. There is a lot of election strategising going on that is not directly tied to the issues discussed.

A narrative analysis of this genre has to try to find what 'story' or 'stories' are told 'behind' the statements of fact; what are taken for granted and shared as common understandings of reality? There are narratives there, behind the facade of matter-of-factness, there are masterplots, there are types; this is what narrative theory applied in this fashion has to seek.

All this taken together probably makes rule-bound political debate one of the most difficult genres to apply this method to. I expect the method to be more successful on other genres, like debate articles, journal articles, Facebook posts and fictional works. But it is also exactly because of the parliamentary debate genre's apparent impregnability that I choose to try.

\section{Analysis: Parliamentary debates}

The Swedish Parliament has 349 members from eight different political parties. The sample of debates I have gone through-somewhere between 20 and 30 hours in total-is no more than a snippet of the total amount of information this institution produces. I have sought those debates where Sami issues, in some way, are debated; for instance, debates around hunting and wildlife management, interpellations about the legal status of the Sami population and Sami Parliament, minority and language issues, and debates around the mining industry. The debates were from 2010 to 2015 .

Generally, the members of the Swedish Parliament agree and restate that the Sami are an Indigenous people in Sweden and, as such, have special rights (with the exception of the Sweden Democrats who, with their nationalistic perspective, do not accept Sami as entitled to Indigenous peoples' rights). Sapmi, on the other hand, seems to be used rather ambiguously as a word to describe the traditional Sami land, best exemplified perhaps by the former Minister of Rural Affairs, Eskil Erlandsson, who called this land 'that which the Sami Parliament calls Sapmi' (Erlandsson 2013). Thereby, he emphasises that calling it Sapmi-a land that is not Sweden-is a Sami idea, not a Swedish one, and in the process discredits its use in national political discourse. In other words, Erlandsson thereby reinforces a narrative of national unity. 
Indeed, the minister is more admitting here than most other MPs. Many refer to this land, if they feel the need, as the 'reindeer-herding territory'. This is interesting because it has historical roots. For a long time, since the first Reindeer Herding Act from 1886, and especially since the Reindeer Herding Act of 1928, the state's perspective was that a real Sami was a reindeer-herding nomad. It ascribed rights to wildlife, forests and water to reindeer herders organised in Sami villages (Ryd and Cramér 2012). This caused a rift within the Sami population, between the reindeer herders and non-reindeer herding Sami, that still exists today. Speaking of this land as 'the reindeer-herding territory' instead of Sami Land (Sapmi) reveals, I believe, the continuation of this understanding of Sami identity — an identity which is difficult to distinguish from the livelihood of reindeer herding. ${ }^{4}$ I would argue that equating Sami people and their interests with reindeer herding is part of a masterplot about Sami culture.

'Sapmi', just like 'Norrland', or indeed 'Sweden'-all these names come with their own narratives, their own perspectives, on this area. Geographically, they do refer to slightly different areas, but choosing to call the lands where Sami have traditionally lived 'Sweden', 'Norrland' or 'Sapmi' reveals different perspectives and thus different narratives, even if the three technically overlap. (Yet another name, especially at the European Union level, is 'the Barents Region'.)

Saying that the Sami are an Indigenous people in Sweden tells a specific narrative too. As an example, one could try reversing it, saying that Sweden is one of the four nations that conquered Sapmi, or even more sharply, that Sweden is one of four states that colonised the Sami people and their lands. The different versions of phrasing are all 'true' depending on perspective, and the different versions come with a certain narrative baggage and thereby a certain understanding of reality.

Regarding the history of colonialism, there are large differences. Some argue that 'Sweden as a great power ... does not have a pretty history' in regards to the Sami population (Skånberg 2012), and some urgently call for ratification of ILO 169. At the other end of the spectrum, history is reversed by MPs claiming that the state 'invented' the south Sami language

4 For an historical view on how the Sami 'race' was equated with reindeer herding as a livelihood, see Lundmark (2008: 141). 
and is trying to expel the true Indigenous people, the mountain farmers and cattle owners in south Sapmi, to unjustly benefit the cherished reindeer herding (Larsson 2013).

One example is especially interesting in this regard, where an MP (Tuve Skånberg, Christian Democrats) shows that he is aware of the 'centuries-old failure of Swedish Sami politics', while at the same time he states, 'It is thus not possible to let a third of the country go to the Sami, even if they have legitimate demands for such a large area' (Skånberg 2012). It is a comparatively honest and knowledgeable speech, but narratively, a number of interesting things happen here. First, the centuries-old Swedish Sami politics are claimed as having failed, which is of course true on some levels, but the way it is said naturalises that Sami politics have been and are part of Swedish politics. Why is it regarded as a natural thing that the Swedish state should have decisive power, throughout the centuries, over Sami and Sapmi in the first place? The underlying premise, the Swedish 'ownership' of this land, is not in question; this 'ownership' is thus part of a shared understanding of reality. The conflicts Skånberg then goes on to describe, where 'by the kitchen table' when he lived in Kiruna 'land owners and Sami even fought', is not understood as a colonial tension between groups, but as a Swedish problem of law, of balancing different interests.

Second, Skånberg's speech is a good example of something I see as a general tendency, namely to regard Sami rights to land and water as a privilege given by a kind Swedish state when historically the order should be reversed-the rights Sami today have are mere scraps of what they ought to have had if the state had not stolen the land. ${ }^{5}$ Letting 'a third of the country go to the Sami' is a narrative where Sweden gives Sami their rights, not a narrative where Sweden has taken a third of what is today 'the country' from the Sami. Add to this the honesty of admitting that the Sami do have legitimate demands for the land and we end up with something that inadvertently comes as close as it gets to formally admitting to present colonialism, or at least unlawful occupation.

In fact, this narrative could be regarded as a form of Swedish masterplot, with the Sami and Sweden (its self-image) as types: Sweden as the giver of rights, the careful balancer of conflicting interests, rather than the

5 'Stolen' might appear as a harsh way of putting it, but it is a paraphrase of Lundmark's 2008 book title, Stulet Land (Stolen Land). 
enabler of continued colonialism. The Sami are seen as being not that bad off, since they can still herd their reindeer, and the reindeer herders still have special rights in relation to average Swedes. Discussions regarding the possible ratification of ILO 169 often have this tendency too, where a continued stalling of the process is not seen as a continued theft of rights from the Sami, but where the possible ratification is seen as an act of generosity. As a generous giver, you are not necessarily compelled to give a gift quickly, so it is more dangerous to hasten into ratification without thoroughly investigating its consequences, than to let the receiver of the gift wait a little longer. Meanwhile, Sweden allows (so to speak) the Sami to continue their reindeer herding, and points of conflictlike the advancement of the mining industry in Sapmi, for exampleare defused with dialogue between industry and reindeer herders (even though the legal framework around mining grants reindeer herders no rights to veto mining projects). This masterplot is thus connected to the idea of Sami as reindeer herders, as it is generally understood that as long as reindeer herding can continue in some fashion, Sami culture is not under immediate threat. Another way of putting it is that, from the state's perspective, the plotline of the masterplot is really not that bad. It can get better, but it is not negative. That there is no immediate threat to Sami culture (since reindeer herding is still going on, Sami = reindeer herder) is, in my opinion, one reason why the two-decade long stalling of the ratification of ILO 169 is not seen as particularly disgraceful. Slowness is rather seen as taking responsibility.

I have stated that masterplots are 'mental maps' which we use to interpret reality. An unusually clear example of this (for the genre) is the MP SvenOlof Sällström (Swedish Democrat) who shapes his narrative like a fairy tale to more clearly evoke the power of colonial masterplots:

Once upon a time there was an explorer who we can call Sven, who together with his crew sailed north along the coast in three ships ... They sought a new and closer road to India. Instead, they found an undiscovered piece of land populated by people with strange clothes, strange habits, and who lived close to nature. During a few centuries, the native inhabitants were banished, their land was stolen, and they were put in reservations. And so ends the story (Sällström 2012).

Sällström then concludes that this was, of course, not how it happened in the Swedish north. The Sami have been subject to atrocities by the state, admits Sällström, but many people, not only Sami, were historically subject to atrocities by the state. The message is that no appropriation 
or colonialism has occurred. 'The wish,' Sällström continues, 'that we in Sweden should have our own "Indians" who need protection from all the misfortunes of the world has overshadowed a correct historiography' (ibid.). The correct historiography, according to Sällström, is that 'the reindeer-herding territory' has been multicultural for centuries, maybe millennia, and therefore the Sami should not receive any special legal treatment or support. He also claims most of the modern reindeer herding in the Scandinavian mountains originated as a result of the war between Sweden and Russia in 1809, and shakes his head in disbelief as he utters the words 'custom immemorial' (ibid.).

The fairy tale narrative is a caricature, not only of the Terra Nullius masterplot (finding 'undiscovered' but still populated lands) but also of the many counter plots and counter narratives to that plot. Sällström also ridicules the Noble Savage masterplot, in that he claims the wish for Sweden to have its own "Indians" who need protecting' has hindered a correct historiography. Interestingly, he ridicules both these colonial masterplots so that he can argue for a legal framework (in hunting and wildlife management) which dispossesses Sami further of their rights as an Indigenous people. Exactly because Sweden's history does not fit the masterplots of colonialism, according to Sällström, Sweden cannot be a colonial state, and thus Sweden should not have a legal framework which in any way treats differently this group of people. In short, the reality does not fit the 'mental maps' of colonial masterplots and therefore the reality must not be colonial. The masterplot that is most fitting to describe the situation in 'Norrland', the way Sällström thinks of it, is the Nation State masterplot—Sällström even makes a point of highlighting that the Sami are also Swedes. ${ }^{6}$

Of the parliamentary debates that I have listened to, I believe this to be one of the most interesting examples of how flexibly masterplots can be deployed as rhetorical tropes; and an interesting example of how narrow the understanding can be of what forms colonialism can take. By sarcastically disproving the colonial masterplots as not fitting to

6 In December 2014, Sällström's party colleague Björn Söder completely reversed this and caused a scandal when he, in an interview, said that Sami (and Jews) are not 'Swedes'. Mainstream media was outraged at Söder's statement, but Sami representatives argued that he was right, and that it was exactly because of this that the Sami have special rights to land and water. 
the Swedish context, Sällström can argue for not only a continued but a radically increased dispossession of the Sami in the name of the nation state- that is, a continuation of colonialism.

One thing I see clearly in the material is that the political discourse on Sami issues in the Swedish parliament in general leans heavily on the Nation State and Development masterplots. Sällström is one example, but another is Ingela Nylund Watz (Social Democrats) who opens a debate about mining with this unifying remark:

There is a broad consensus in Sweden about the importance of the mining industry. It has in the past, and will in the future, constitute an important foundation for our ability to maintain employment and welfare (Nylund Watz 2014).

No eyebrows are raised. This is a 'statement of facts' common to all political parties' understanding of the mining industry, repeated in various forms by many. That is why it works well as an example of a common narrative understanding of reality, part of a masterplot. The narrative here is one of national unity, of a common history and a common future.

Mining especially, closely followed by hydropower and forestry, are raw material industries primarily established in Sapmi, with resources and money flow going pretty much one-way from Sapmi to Sweden. Of all the ore produced in Sweden, over 90 per cent comes from Norrbotten, from Kiruna and Gällivare municipalities (Hedström 2012). These mines are undisputedly in ('what the Sami Parliament calls') Sapmi. The large dammed rivers and the vast felled forests of Sapmi are routinely cherished as primary industries foundational for Sweden as a state and/or the welfare state (Persson 2014)— though, just as routinely, the Sapmi part is missing from the narrative. It is extremely rare to find explicit references to Sapmi or even to Norrland when speaking of these industries. The national narrative, of Sweden rising to become a modern nation, veils the fact that this ascent was largely accomplished by resources appropriated through colonial means in Sapmi. Nylund Watz does, however, slip a little when saying that the renaissance in the mining industry 'actually is a concern for the whole country' (Nylund Watz 2014). ${ }^{7}$ It might appear petty to focus on that word-'actually'-but it does reveal that this is not

7 In the address, Nylund Watz emphasises 'actually', though in the written records there are no italics. 
normally the case; normally, mining does not concern the whole of the country. Normal, historically, is that mining belongs to a certain area of the country, particularly the north, that is, Sapmi.

I would like to point out that I do not doubt the minerology, that Sapmi is rich in mineral and other natural resources. What I do question is the basically undisputed, self-appointed right of the Swedish state to directly exploit, or enable others to exploit, those resources without even granting the Sami the right to veto or dispute. Such organisation, especially combined with the continued stalling of the ratification of ILO 169, and coupled with an overtly nationalistic rhetoric surrounding the mining industry (or extractive industries in general), are all part of a narrative about the mining industry which distinctly underplays its colonial structure and operations. The existence of this narrative, and the virtual absence of dissent to it in the discourse, is an example of a shared colonial mindset.

\section{Summary of analysis}

Constructing one concise masterplot which shapes the narratives surrounding the relationship between the Swedish state and Sapmi could be summarised as follows. The state has done bad things to Sami in the past, but, exactly what that was, is rather vaguely described most often. In the material I have gone through, I cannot recall a single instance of the word 'colonialism' actually being used, even when describing the past. Sweden, as a type in a masterplot, is pictured as kind, a giver rather than a taker of rights, an upholder of equality, democracy and responsibility. The stalling of the ratification of ILO 169, for instance, is seen mainly as a sign of taking responsibility in a delicate situation of conflicting interests rather than a continuation of withholding human rights from the Sami. I believe the state, as a type, downplays its own actions that enable modern colonialism, and do not sufficiently acknowledge historical acts of colonialism. Indeed, those historical acts of colonialism are pictured as national success stories which everyone within the borders of the country ought to be thankful for and proud of. The extractive industries, which in my opinion (and doubtless that of many Sami as well) embody and act as the motivation for Swedish colonialism, are what 'built' the country. The narratives around these industries thus serve a nationalistic function. Particularly—it seems - the narratives around mining get to carry this 
nationalistic, unifying function. These industries have been and still are located to an extensive degree in Sapmi, drawing wealth from Sapmi to Sweden. At the same time, Sami communities are not given the possibilities to oppose them or benefit from them. This unequal relationship, in the material I have gone through, is never acknowledged.

The Sami as a type are often equated with reindeer herders, and Sapmi is 'the reindeer-herding territory' (in other words, an area within Sweden where some have this 'job'). Since the reindeer herders are still going about their business, there is obviously no immediate danger to Sami culture. Indeed, many times it seems that Sami issues literally translate to reindeerherding issues. For instance, this is seen in discussions about ILO 169, which are relevant for more Sami than just reindeer herders. Constructing Sami as a type in this fashion diminishes Sami culture (which is more diverse), ignores the non-reindeer herding Sami population to a large degree, and draws attention away from the state's maintaining of policies which make the Sami effectively powerless, and which cause division within the Sami population.

The plotline in this masterplot is thus a progressive one. It was worse before but it is getting better, even if it takes some time to get there. The plotline seems to follow closely the idea of progression of the Swedish state as a type, from feudal and oppressive to capitalistic, democratic and modern. The plotline thus follows the modernistic assumption of linear development, that things always get better, more evolved, developed and just over time.

\section{Concluding remarks}

When working with my master's thesis, I ran into problems. What I wanted to explore and expose was not there to be found in the material I wanted to analyse. No one in decision-making institutions in mining affairs in Sweden expressed anything remotely colonial, at least not on the surface of it. In the parliament, in government reports, in agency decisions and historiographies - everything seemed so very nice and rational. At the same time, looking at what decisions were actually made, hearing Sami friends and colleagues describe a completely different reality (counter narratives), and having experiences from being an activist protesting mining operations on site in Sapmi, it was painfully obvious to me that 
there existed a discrepancy between the narratives in mainstream politics and the actual practices those narratives brought about. I needed to find a way to pry open what appeared as a closed box within the Swedish political discourse on Sami issues.

In narrative theory, I believe I have found one such leverage tool. Part of the advantage of this method is that it helps a reader to ask and critically examine what is excluded from descriptions of reality (narratives) instead of looking only at what is included. That is a key difference, as I see it, between what I try to do with narrative theory and what is commonly done in discourse analysis more broadly. It is also a method which is easier to apply to larger sets of text and full arguments, rather than to the meaning of individual words or short sentences, to examine how meaning changes over time and in different contexts. It is far from a finished, complete methodology, but it is a start-at least for my own thinking and writing.

My method demands an understanding of counter narratives, and that one is flexible enough to question what is taken for granted and objective in a discourse. My understanding of counter narratives is theoretical. It comes from friends and literature, not from my own personal history. With personal experiences of having lived through, and still being threatened by, colonial practices and racist attitudes, even greater credibility and quality could most likely be lent to academic works applying this or similar methods.

Had I not, by chance, come into close contact with counter narratives half a decade ago, I would most certainly still subscribe to a masterplot which diminishes Sami culture, glorifies colonial industries and portrays the perpetrator/enabler as wise, righteous and fair. Because I heard counter narratives, met and befriended people who lived with the heritage of colonialism, I changed my perspective. My 'world' changed. I am therefore an example of the importance of counter narratives, of the telling of Sami narratives and world views. I cannot speak or do research from the perspective of the colonised, but I can speak and do research from the perspective of one who has lived most of his life benefiting from colonialism without being aware of it. I can try and combat that widespread unawareness, in academia and as an activist. That is what my contribution can and should be in revitalising Sami culture. 


\section{References}

Abbott, Porter H. 2008. The Cambridge Introduction to Narrative. Cambridge: Cambridge University Press.

Cronon, William. 1992. 'A place for stories: Nature, history, and narrative'. The Journal of American History 78(4): 1347-76. doi.org/10.2307/2079346

Erlandsson, Eskil. 2013. 'Interpellation 2012/13:488'. Sveriges Riksdag, 15 August. Online: www.riksdagen.se/sv/Debatter--beslut/Interpellations debatter1/Debatt/?did=H010488 (accessed 21 August 2018).

Hagström Yamamoto, Sara. 2010. I gränslandet mellan svenskt och samiskt: identitetsdiskurser och förhistorien I Norrland frän 1870-tal till 2000-tal [In the borderland between what is Swedish and what is Saami: Discourses of identity and pre-history in Norrland from 1870 to 2000]. Uppsala: Uppsala Universitet, Institutionen för Arkeologi och Antik Historia.

Hedström, Jan-Olof. 2012. Igenom gode Ordningar och flitigt uppseende: Bergsstaten 375 ar [Through good order and diligent attention: Bergsstaten 375 years]. Uppsala: Bergsstaten, Sveriges geologiska undersökning (SGU).

Jameson, Fredric. 1981. The Political Unconscious: Narrative as a Socially Symbolic Act. Ithaca and London: Cornell University Press.

Lahtinen, Sara. 2012. 'A valuable void: How nostalgic reminiscence and grief over a lost past constitutes part of cultural identity'. MA thesis, Stockholm University. Online: su.diva-portal.org/smash/record.jsf?pid=diva 2\%3A584359\&dswid=3340 (accessed 23 August 2018).

Larsson, Olle. 2013. 'Interpellation 2012/13:488'. Sveriges Riksdag, 15 August. Online: www.riksdagen.se/sv/Debatter--beslut/Interpellationsdebatter1/Debatt/ ?did=H010488 (accessed 7 September 2018).

Lundmark, Lennart. 2008. Stulet land: Svensk makt på samisk mark [Stolen land: Swedish power in Saami land]. Stockholm: Ordfront.

McLeod, John. 2000. Beginning Postcolonialism. Manchester: Manchester University Press.

Nylund Watz, Ingela. 2014. 'Betänkande 2013/14:NU14'. Sveriges Riksdag, 19 March. Online: www.riksdagen.se/sv/Debatter--beslut/Debatter-och-beslutom-forslag/Arendedebatter/?did=H101NU14 (accessed 22 August 2018).

Persson, Kent. 2014. First speech in Debatt och beslut: Mineralpolitiska frågor, 19 March. 
Regan, Paulette. 2010. Unsettling the Settler Within: Indian Residential Schools, Truth Telling, and Reconciliation in Canada. Vancouver: University of British Columbia Press.

Reindeer Herding Act, 1886, Svensk författnings samling [Swedish Code of Statutes], SFS 1886: 38.

Reindeer Herding Act, 1971, Svensk författnings samling [Swedish Code of Statutes], SFS 1971: 437. Online: lagen.nu/1971:437 (accessed 11 September 2018).

Ricour, Paul. 1983. Time and Narrative. Chicago: University of Chicago Press.

Ricœur, Paul. 1991. 'Life in quest of narrative'. In On Paul Ricœur: Narrative and Interpretation, edited by David Wood, 20-33. London: Routledge.

Ryd, Lilian and Tomas Cramér. 2012. Tusen år i Lappmarken - Juridik, skatter, handel och storpolitik [A thousand years in Lapland - law, taxes, trading and politics]. Skellefteå: Ord\&visor förlag.

Sällström, Sven-Olof. 2012. 'Betänkande 2011/12:MJU13'. Sveriges Riksdag, 28 March. Online: www.riksdagen.se/sv/Debatter--beslut/Debatter-och-beslutom-forslag/Arendedebatter/?did=GZ01MJU13 (accessed 21 August 2018).

Skånberg, Tuve. 2012. 'Betänkande 2011/12:KU17’. Sveriges Riksdag, 23 May. Online: www.riksdagen.se/sv/Debatter--beslut/Debatter-och-beslut-om-forslag/ Arendedebatter/?did=GZ01KU17 (accessed 21 August 2018).

Smith, Linda Tuhiwai. 1999. Decolonizing Methodologies: Research and Indigenous Peoples. London: Zed Books.

Sörlin, Sverker. 1988. Framtidslandet: debatten om Norrland och naturresurserna under det industriella genombrottet [The land of the future: The debate about Northern Sweden and its resources through the industrial era]. Stockholm: Carlssons.

Thiong'o, Ngũgĩ wa. 1986. Decolonising the Mind: The Politics of Language in African Literature. Nairobi: East African Educational Publishers.

Tobias, Ronald B. n.d. 20 Master Plots and How to Build Them. Online: www.writersdigest.com/wp-content/uploads/Master-Plots-Exclusive.pdf (accessed 21 August 2018). 
This text is taken from Indigenous Efflorescence: Beyond Revitalisation in Sapmi and Ainu Mosir, edited by Gerald Roche, Hiroshi Maruyama and Åsa Virdi Kroik, published 2018 by ANU Press, The Australian National University, Canberra, Australia.

doi.org/10.22459/IE.2018.01 